Nederlandse Letterkunde

http://letterkunde.letterentijdschrift.nl

Uitgave: Amsterdam University Press

\title{
Autie-biografisch gelezen
}

Het spanningsveld tussen taal, narrativiteit en autisme

Leni Van Goidsenhoven

NEDLET 23 (1): 71-100

DOI: 10.5117/NEDLET2018.1.GOID

\begin{abstract}
Reading Autie-Biographically: The Field of Tensions between Language, Narrativity and Autism

Within the current disability memoir boom, the popularity of autism narratives makes it almost impossible to keep up with its publication flow. This implies that there is a growing market for those stories, and indeed, several publishing companies are even specialized in these memoirs. However, when autism memoirs - also called 'autie-biographies' - are incorporated in research, they often merely function as 'illustrations' of an hypothesis, which leads to a reductive understanding and reading practice of those narratives as mere evidence for diagnostic categories. Such a diagnostic mode of reading offers almost no space for asking broader interpretative questions about different relations to language or narrative structure. In the present article, my aim is to study the complex tension between autism, language and narrativity and to propose a hypothesis about the reasons behind the dominance of the diagnostic reading mode within different research disciplines, including literary studies. I do so by focusing on the ubiquity of three recurring issues in the reception of autie-narratives: the window metaphor, the narrative identity thesis, and clinical perspectives. At stake in this research is the continual questioning of what constitutes of a self-narrative, and within this, to ask, who may and can speak, who is and can be considered to be a competent storyteller.
\end{abstract}

Keywords:: disability memoires, autism, self-narrative, autie-biography, diagnostic reading, literary studies, Landschip 


\section{$1 \quad$ Inleiding}

Personen met autisme ${ }^{1}$ hanteren niet altijd een talige en conventionele manier van communiceren. Daar komt bij dat ze houden van repetitieve handelingen en schijnbaar louter in zichzelf zijn gekeerd, alsof ze geen interesse hebben in wat rondom hen gebeurt. Mede door dergelijke stereotiepe en uiterlijke verschijnselen ging men er dan ook lang vanuit dat mensen met autisme bijna geen subjectiviteit of zelf hadden. Bijgevolg waren ze niet meteen het meest favoriete onderwerp voor verhalenvertellers. Ze werden voornamelijk beschouwd als oninteressante en oppervlakkige subjecten. $^{2}$

Eind jaren tachtig werd autisme echter een gemeenplaats van (populaire) cultuuruitingen, zoals films, romans, series, maar ook theater, talkshows, radioprogramma's, met binnen de literatuur J. Bernlefs Vallende ster (1989) en Mark Haddons The Curious Incident of the Dog in the Night-Time (2003) als belangrijkste en meest populaire exponenten. Het is vandaag lang geen overdrijving meer om te stellen dat 'the figure or the autistic individual has become a narrative marker of fascination for much cultural production across different media'. ${ }^{3}$ De explosieve interesse in autisme en cognitieve andersheid in het algemeen wordt enerzijds gevoed door een breder begrip vanuit neurowetenschappelijk onderzoek ten aanzien van neurologische stoornissen, anderzijds is er nog grote onwetendheid en hangt er een prikkelend mysterie rond neurologische en psychiatrische condities als autisme. Juist deze dualiteit intrigeert verhalenvertellers en kunstenaars blijkbaar mateloos. ${ }^{4}$

Kritisch onderzoek vanuit een breed academisch draagvlak naar de discursieve uitdijing en groeiende culturele productie rond autisme kwam op gang in het eerste decennium van de eenentwintigste eeuw. ${ }^{5}$ Vooral populaire en fictionele autismerepresentaties worden geëxploreerd en geanalyseerd; het gaat daarbij vooral om representaties gecreëerd door mensen die niet op het autismespectrum leven. Specifiek worden (stereo)typen, narratieve en retorische constructies in kaart gebracht. Hiermee trachten onderzoekers niet enkel inzicht te krijgen in de discursieve vormgeving van autisme, maar ook in wat het betekent om met autisme te leven. Willen we echter inzicht krijgen in autisme-ervaringen, dan lijkt het me aangewezen om ons niet blind te staren op bijvoorbeeld de veelbesproken roman als Bernelfs Vallende ster, maar ook life writing, memoirs of interviewtranscripties te rekenen tot object van letterkundig en literatuurwetenschappelijk onderzoek.

Autismezelfverhalen zijn ontzettend populair en de publicatiestroom 
(zowel off- als online) is onmogelijk bij te houden. Wanneer autismezelfverhalen echter aan bod komen in autismeonderzoek, functioneren ze meestal als 'illustraties' van hypothesen. Ze worden dan ook vaak benaderd via een 'diagnostische' of 'symptomatische leespraktijk'. ${ }^{6}$ Dit wil zeggen dat tekstuele kenmerken op een onkritische manier rechtstreeks in verband worden gebracht met symptomen van autisme, zoals bijvoorbeeld het (relatieve) ontbreken van narratieve coherentie en metaforisch taalgebruik, of de voorkeur voor repetitieve patronen en structuren. Een dergelijke leespraktijk laat niet toe om in te gaan op het performatieve karakter van dergelijke verhalen, noch op de manier waarop ze inzichten en vertogen kunnen denaturaliseren, destabiliseren en transformeren. Meer zelfs, er is geen ruimte om bredere interpretatieve vragen te stellen over bijvoorbeeld alternatieve verhoudingen tot taal, narratieve structuur of subjectiviteit: 'The diagnostic mode', stelt Michael Bérubé, 'then leads us away from the grainy details of specific passages and utterances, distracting us from what we should be asking about narrative as such. ${ }^{7}$

In deze bijdrage wil ik nagaan hoe het komt dat er zo weinig kritische aandacht is voor wat er in autismezelfverhalen op vormelijk niveau gebeurt en waarom de diagnostische leespraktijk zo dominant is binnen vele onderzoeksdisciplines. Een korte bespreking van de receptie van enkele internationaal bekende autismezelfverhalen zal meteen illustreren dat autistische mensen vaak niet als volwaardige en complexe individuen worden gezien. Specifiek wordt ingegaan op de drie meest voorkomende receptieve reacties die bovendien allen te maken hebben met het complexe spanningsveld tussen autisme enerzijds en taal en narrativiteit anderzijds. Vanuit die receptieve reacties gaan we vervolgens dieper in op deze spanning. Meer specifiek zal ik deze spanning exploreren aan de hand van de alomtegenwoordigheid van de venstermetaforiek en de narratieve identiteitsthese. Zowel in het gebruik van de venstermetaforiek als in de narratieve identiteitsthese zal het belang van (zelf)verhalen heel nadrukkelijk naar voren komen. Willen we (h)erkend worden als subject, dan eist het systeem namelijk een (zelf)verhaal. Dat (zelf)verhaal, zo zal blijken, wordt binnen autismeonderzoek (en binnen life narratives in het algemeen) echter vaak op een eenduidige en normatieve manier geconceptualiseerd.

Een normatieve conceptualisering van wat een (zelf)verhaal moet zijn, heeft echter verregaande gevolgen in het (h)erkennen van subjecten die moeilijker vertellen of subjecten die geen conventionele taal hanteren. Het is dan ook significant om ons voortdurend te blijven afvragen wat een zelfverhaal is en bijgevolg wie mag en kan spreken, wie er al dan niet beschouwd wordt als een 'competent verteller'. Met deze vragen gaan we 
dan ook aan de slag en dit onder meer door gebruik te maken van enkele klinische perspectieven. Zo kunnen we via de lokale- en centralecoherentiehypothese niet enkel de stelling tegenspreken dat autistische mensen geen complexe subjecten zijn, maar kan er ook voldoende aandacht worden besteed aan hun specifieke cognitieve stijl met eigen vaardigheden.

Niettemin, zo zal blijken, steunen klinische perspectieven nog te veel op een klassiek subjectiviteitsidee. Om voorbij te gaan aan dat klassieke subjectiviteitsidee - en dus meer ruimte te maken voor andere verhalen moeten we meer recht doen aan het heterogene karakter van autismezelfverhalen zelf. Aan de hand van een analyse van het werk van de Vlaamse kunstenaar Landschip zal ik dan ook de contouren schetsen van een alternatieve leespraktijk, die meer oog heeft voor andersoortige vormen van narratieve ordening en betekenisgeving.

\section{Drie receptieve reacties op autie-biografieën}

Sinds grofweg eind jaren negentig van de vorige eeuw is er een wildgroei aan autismezelfverhalen. Deze proliferatie staat uiteraard niet op zichzelf, maar is verbonden aan en functioneert binnen een breder cultureel fenomeen, namelijk de hedendaagse memoir boom. ${ }^{8}$ De veelheid aan dergelijke verhalen impliceert meteen dat er een markt voor is. ${ }^{9}$ Er zijn zelfs uitgeverijen die zich specialiseren in de publicatie van zelfverhalen van mensen met autisme en er bijgevolg categorieën, series en catalogi voor creëren, zoals Jessica Kingsley Publishers, Autism Asperger Publishing Company, of Future Horizons.

Wanneer we echter een blik werpen op de receptie van de autismezelfverhalen zien we dat ze aanvankelijk vooral reacties van ongeloof en wantrouwen uitlokten: 'Waren ze wel echt geschreven door personen met autisme?'10 Argwaan ontstaat vooral als het niet meteen duidelijk is 'wie spreekt' of 'wie schrijft'. Discussies over 'authenticiteit' laaien dus op bij teksten geschreven door mensen met autisme die niet spreken, maar wel schrijven en dit al dan niet met behulp van ondersteunde of gefaciliteerde communicatietechnologie. Voorbeelden hiervan zijn er te over: Tito R. Mukhopadhyay, Naoki Higashida, Birger Sellin, Larry Bissonnette, Lucy Blackman, Deej Savarese, enzovoort. Ook gepubliceerde teksten waarbij een coauteur is betrokken, zoals in het geval van Temple Grandin en Scariano, worden met wantrouwen benaderd. Francesca Happés symptomatische lectuur van Grandins Emergence (1986) is een goed voorbeeld van zo'n wantrouwige houding. Happé, die een vooraanstaand en invloedrijk 
neurocognitief wetenschapper gespecialiseerd in autisme is, vroeg zich expliciet af of de tekst al dan niet betrouwbaar representeert waar hij aan refereert - dit niet vanuit een epistemologische twijfel tegenover het eigen 'niet-autistische' perspectief, maar vanuit de vraag 'how able' of 'how handicapped' de auteur precies is. ${ }^{11}$ Happé ging er daardoor vrij snel van uit dat de fragmenten waarin de ik-verteller blijk geeft andermans emoties te begrijpen, of die waarin ze vertelt over vriendschap of enige verbeelding aan de dag legt, niet geschreven konden zijn door Grandin zelf, maar wel door Margaret Scariano, haar coauteur.

Een tweede reactie die aanvankelijk veel voorkwam en enigszins aansluit bij de wantrouwige houding, is de opvatting dat de zelfverhalen geschreven zouden zijn door diegenen die hun 'autisme ontgroeien'. Deze (controversiële) opvatting lezen we niet enkel in oude boekrecensies, maar ook in verschillende inleidingen van zelfverhalen uit de jaren negentig. Zo schreef Friedrich Specht dat Dietmar Zöllers' relaas Wenn ich mit euch reden könnte... (1989) getuigenis aflegt van 'hoe een autistische ontwikkeling wel degelijk tot een vorm van zelfstandigheid kan leiden die eigenlijk niet meer autistisch kan worden genoemd. ${ }^{12}$ Bernard Rimland - een vader van een zoon met autisme alsook een medische autoriteit op het gebied van autismeonderzoek - schreef in zijn inleiding op Grandins eerste boek hoe Grandin langzaamaan haar autisme 'ontgroeit', hoe ze van een 'zeer ernstig gehandicapt' kind dat geïnstitutionaliseerd zou moeten worden, uitgroeit tot een 'zelfstandig, krachtdadig en productief subject', een subject dat door de maatschappij makkelijker erkend wordt en naar waarde wordt geschat. ${ }^{13}$ Als inleiding op Donna Williams' Nobody Nowhere (1992) schreef Rimland iets gelijksoortigs: 'Very few made the almost superhuman transition from autism to near-normalcy. ${ }^{14}$ Rimland hanteert duidelijk de triomfretoriek en suggereert dat zowel Grandin als Williams - de eerste twee auteurs die met hun zelfverhaal wereldwijd een heel breed publiek bereikten - een ontwikkeling hebben doorgemaakt die hen haast boven hun autisme tilt. Hij bestempelt deze daadkracht bij Williams ook uitdrukkelijk als een bovenmenselijke daad, waardoor een savantretoriek binnensluipt.

Deze savantretoriek brengt me meteen bij een derde veelvoorkomende reactie op de eerste gepubliceerde autismezelfverhalen. In plaats van wantrouwen op te roepen, of gelezen te worden als een bewijs dat iemand haar of zijn autisme ontgroeid zou zijn, werden autie-biografieën ook weleens vol ontzag onthaald. Zulke verhalen werden daarbij niet enkel bejubeld, maar vooral gekoppeld aan het savantvertoog en dus gekarakteriseerd als 'buitengewoon', 'extraordinair', 'ondenkbaar' en 'verbijsterend' - woorden 
die vaak prijken op de kaften van dergelijke boeken. Ook dit receptieve aspect vinden we regelmatig terug in teksten die de zelfverhalen introduceren. Zo omschreef Oliver Sacks het boek Emergence van Grandin als een bijna ondenkbare tekst: '[U]nthinkable because it has been medical dogma for forty years or more that there was no "inside", no inner life, in the autistic. ${ }^{15}$ Michael Klonovsky schreef als introductie op Birger Sellins $i k$ wil geen inmij meer zijn. berichten uit een autistische kerker (1993) dan weer het volgende:

De teksten kwamen per post, en ik was sprakeloos. Zoiets had ik nog nooit gelezen. Dat was niet het gestamel van een waanzinnige, die niets van zijn medemensen wil weten $[\ldots]$. Dat waren uit grote nood losbarstende, diep overschaduwde, eenzaamheidsbeladen en mysterieuze teksten in een ongemeen compacte taal. ${ }^{16}$

Klonovsky schrijft vol ontzag over de teksten van Sellin, maar hanteert daarbij een retoriek die hem als 'mysterieuze en tragische ander' karakteriseert. De auteur wordt neergezet als iemand die, hoewel hij zijn leven moet doorbrengen in een zogenaamde 'duistere wereld', verrassend genoeg meer kan dan enkel 'stamelen' als een 'waanzinnige': buiten alle verwachtingen in schrijft hij in een 'ongemeen compacte taal'. Het citaat maakt duidelijk dat een dergelijke retoriek de autistische auteurs van de zelfverhalen opnieuw in een uitzonderingspositie plaatst, namelijk die van de savant. In plaats van te focussen op wat de zelfverhalen zouden kunnen teweegbrengen, wordt de nadruk eenzijdig gelegd op het bovenmenselijke, sensationele en spectaculaire talent. Dit werkt bijgevolg vreemde waardeoordelen in de hand: wie autisme heeft, zou maar beter ook een spectaculair talent bezitten - anders is de persoon al helemaal niet interessant.

Hoewel er bij de zojuist geschetste houdingen tegenover gepubliceerde autismezelfverhalen al terecht vraagtekens zijn geplaatst, ${ }^{17}$ is het niet moeilijk om te begrijpen waar ze vandaan komen. De reacties, hoe verschillend ze onderling ook zijn, hebben allemaal te maken met het spanningsveld 'taal en autisme'. Zo vertrekken ze onder meer vanuit een en hetzelfde denkkader - een denkkader dat ik hieronder nader zal exploreren via de metafoor van het venster. Daarnaast houden ze verband met de dominantie van de narratieve identiteitsthese enerzijds en met de klinische categorie autismespectrumstoornis anderzijds. Deze houdingen leiden ertoe dat er vooral interesse wordt geuit in de 'waarheid' achter het verhaal en er minder tot geen aandacht wordt besteed aan hoe de zelf- 
verhalen autisme constitueren - en zo een subjectiviteit creëren die cultureel beschikbaar wordt gemaakt.

\subsection{De venstermetaforiek}

Wanneer we naar de achterflappen van autismezelfverhalen kijken of naar meer theoretisch gerichte studies over deze zelfverhalen, dan valt het op dat die 'waarheid achter het verhaal' vaak vorm krijgt via de venstermetafoor - een metafoor die suggereert dat lezers via het voorliggende verhaal ergens naar binnen kunnen kijken:

In dit autobiografische verslag leren we autisme kennen van binnen uit. ${ }^{18}$

Achter de schermen mogen kijken van mensen met hoog functionerend autisme, helpt ons ongetwijfeld om meer begrip op te brengen voor hun moeheid van leven $[\ldots] .^{19}$

Autistic narratives $[\ldots]$ have provided a window into autistic experience. ${ }^{20}$

Deze venstermetafoor benadrukt het zogenaamde mimetische of transparante karakter van het verhaal. Dit wil zeggen dat er voornamelijk gesteund wordt op een referentiële taalopvatting: een vorm van representatiedenken die weinig stilstaat bij eventuele epistemologische valkuilen. De gepubliceerde zelfverhalen bieden de lezer een unieke en ongemedieerde blik op de ervaringswereld van mensen met autisme, zo is de suggestie. Men gaat dus uit van het idee dat taal min of meer transparant is; een betekenaar geeft vorm aan een betekende in de buiten-talige wereld en op die manier wordt communicatie tussen competente talige subjecten mogelijk. De venstermetaforiek impliceert dat de tekst niets minder (maar ook niets anders) dan een betrouwbare 'beschrijving' of 'representatie' kan geven. Elke complexiteit van zelfrepresentatie wordt bijgevolg uit de weg gegaan en de autobiografische tekst wordt op een lineaire manier verbonden met de cognitieve conditie van de auteur.

Dit denkkader - waarbij de aandacht dus louter en bijna ongemerkt uitgaat naar datgene wat 'achter' de woorden ligt en waarbij geen ruimte is om iets langer bij de woorden zélf te blijven hangen - zit ook vervat in wat we hieronder de narratieve identiteitsthese zullen noemen en hoe er, conform deze these, naar de relatie tussen taal, communicatie en autisme wordt gekeken. Het ligt op zijn beurt ook aan de basis van zowel wantrouwige houdingen tegenover autismezelfverhalen, het oudere, intussen controversieel geworden idee dat de auteurs hun autisme ontgroeid zouden 
zijn, alsook de opvatting dat ze een bovenmenselijke daad stelden met het schrijven op zich.

\subsection{Narratieve identiteit}

Wanneer het over het spanningsveld gaat tussen autisme, taal en communicatie gaat het ook meestal over narrativiteit. Autisme als conditie wordt nog steeds vaak beschouwd als 'peculiarly resistant to narrative,, ${ }^{21}$ of als 'incompatible with Western notions of progress as people on the spectrum tend to abhor change and transformation, which are features we traditionally expect from narrative'. ${ }^{22}$ In Autism and Representation (2008) beargumenteert Mark Osteen ook dat zelfverhalen van mensen met autisme 'frequently display a tension between the demands of narrative cohesion and the obligation to tell the truth. [...] They maintain a conflicted relationship with narrative, often either lapsing into convention or eschewing narrative cohesion altogether. ${ }^{, 23}$ Autismeverhalen worden vervolgens gekarakteriseerd als 'fragmented and disrupted, consisting of disconnected episodes'. $^{24}$

Dat deze karakterisering voornamelijk gebeurt in termen van tekorten en gebreken impliceert dat er stilzwijgend wordt uitgegaan van een norm van een traditionele vorm van narratieve constructies waarbij een verhaal essentialistisch gedefinieerd wordt aan de hand van distinctieve kenmerken. Dit wil zeggen dat een (goed, normaal) verhaal een lineaire structuur heeft en gekenmerkt wordt door een plot, logische causaliteit, synthese en een eenheid die ruimtelijk en temporeel geordend zijn. Bovendien is er ook meestal sprake van cognitieve referentialiteit. Zonder enige nuance of kritische reflectie verbinden zulke visies over autismezelfverhalen een narratieve constructie meteen aan een 'zelf' en aan een specifieke cognitieve conditie.

De opvatting dat autobiografische verhalen essentieel zijn voor de constructie van een zelf - 'ik praat dus ik ben' - is sinds midden jaren zeventig wijdverspreid en staat vooral bekend als de 'narratieve identiteitsthese'. ${ }^{25}$ Het concept steunt het idee dat er geen prediscursief zelf of subject bestaat onafhankelijk van het (conventionele) spreken. Het subject is geen inherent gegeven, kent geen kern en is niet stabiel, maar wordt voortdurend geconstrueerd en gereconstrueerd in, door en met verhalen die het subject over zichzelf vertelt: het subject geeft zichzelf reflexief vorm via de taal. De verhalen zijn evenmin een gegeven, ze krijgen pas vorm in en door het vertellen van het subject. Vaak wordt impliciet verondersteld dat diegene die vertelt zich kan positioneren binnen bestaande vertogen - en indien gewenst zich ook kan verzetten tegen specifieke vertogen of subjectposi- 
ties. De meest befaamde psycholoog die de intieme link tussen identiteit en narrativiteit exploreerde, is Jerome Bruner. Bruner kreeg al snel aanhang vanuit verschillende wetenschappelijke disciplines en de narratieve identiteitsthese werd mede daardoor een op zichzelfstaand paradigma.

De Portugese neuroloog Antonio Damasio bestudeerde eveneens de link tussen narrativiteit, subjectiviteit en identiteit. Hij is in de literatuurwetenschappen vooral bekend om zijn neurobiologische bewustzijnstheorie waarin hij het heeft over een 'narratieve kern': 'The story contained in the images of core consciousness is not told by some clever homunculus. Nor is the story told by you as a self because the core you is only born as the story is told, within the story itself. ${ }^{26}$ De Amerikaanse neuroloog Michael Gazzaniga zegt iets gelijksoortigs en beschouwt 'the self as the product of stories we tell about ourselves'. ${ }^{27}$ Hij benadrukt dat er biologisch gezien geen zelf is, enkel de illusie van een zelf, die gecreëerd wordt in en door verhalen. De opvatting dat er geen primaire biologische basis is voor het hebben van een zelf, maar dat het veeleer een secundaire constructie is waarbij narrativiteit een organiserende rol heeft, wordt door talrijke (neuro)wetenschappers beaamd. Het belang van narrativiteit als organiserende rol wordt door sommigen zo sterk benadrukt dat vertellen over het zelf een voorwaarde is voor het hebben en behouden van een zelf.

Een cruciale vraag is natuurlijk over welk soort verhalen het hier gaat. Als het (reflexief) vertellen over het zelf zo belangrijk is, hoe ziet die vertelling er dan uit, over welk soort verhaal heeft men het? Wanneer we er Bruners, Damasio's en Gazzaniga's werk op naslaan, wordt het duidelijk dat het concept 'narratieve identiteit' voornamelijk verbonden wordt met een 'coherent verhaal'. Onder een coherent verhaal wordt een aristoteliaans goed gestructureerd verhaal begrepen met een duidelijke lineaire temporaliteit of logisch-causale samenhang van de vertelde reeks gebeurtenissen. ${ }^{28}$ Het verhaal heeft een begin, midden, slot en een thematische compleetheid of hoge graad van wat men in de narratologie 'resolution' noemt. ${ }^{29}$ Er wordt uitgegaan van de opvatting dat het leven zodanig polyinterpretabel is en geen compleetheid kent dat personen, willen ze kunnen overleven, behoefte hebben aan een coherent en duidelijk geordend verhaal over zichzelf. ${ }^{30}$ Coherentie staat hier bijgevolg garant voor kwaliteit; het is de norm voor een 'goed' verhaal.

Een belangrijke consequentie van deze gedachtegang is dat mensen die over zichzelf praten aan de hand van een coherent en samenhangend verhaal psychologisch gezond zijn, terwijl mensen die over zichzelf praten aan de hand van incoherente verhalen psychologische problemen hebben. ${ }^{31}$ Dit wordt ondersteund door het therapeutische post-freudiaanse 
vertoog dat een coherent zelfverhaal als het ultieme einddoel van een genezingsproces beschouwt. ${ }^{32}$ Kortom, de narratieve identiteitsthese wordt voornamelijk gethematiseerd in termen van eenheid, volledigheid en coherentie en heeft weinig aandacht voor meerduidigheid, complexiteit en creativiteit.

De correlatie tussen conventioneel taalgebruik, coherente autobiografische vertellingen en een psychisch welzijn heeft echter verreikende gevolgen. De opvatting impliceert niet enkel het idee dat taal transparant is, maar ook dat individuen 'ziek' zijn wanneer ze geen coherent zelfverhaal kunnen vormen of geen conventionele taal kunnen hanteren. Want, zo gaat de redenering, hoe kan er sprake zijn van denken, bewustzijn of een zelf zonder taal, zonder coherent verhaal? Deze denkwijze gaat er dus van uit dat individuen die niet of moeilijk spreken (denk aan autisme, maar ook aan alzheimer of afasie) een minder gevormd of zelfs geen zelf hebben. De vraag is echter of die mensen geen zelf hebben of dat ze vanwege dominantie van een bepaalde visie niet als dusdanig kunnen worden (h)erkend. ${ }^{33}$ Aansluitend daarbij is het zinvol om ons af te vragen of coherentie wel het belangrijkste verhalende element is. Is de coherentie het basiselement van narratieve zelfheid? Wat zijn mogelijke andere manieren om te vertellen, of om naar zelfverhalen en die subjecten die ze vertellen te kijken?

Met deze bovenstaande vragen gaan we hieronder aan de slag. Meer specifiek kijken we eerst naar enkele klinische perspectieven - en met name de lokale- en centralecoherentiethese - die ons kunnen helpen in het tegenspreken over het feit dat mensen met autisme geen complexe individuen zouden zijn.

\subsection{Het klinische perspectief}

De categorie 'autismespectrumstoornis' schrijft voor dat kwalitatieve stoornissen in taalgebruik en in verbale en non-verbale communicatie tot de belangrijkste symptomen behoren. ${ }^{34}$ Heel wat mensen met autisme (al dan niet gecombineerd met een verstandelijke beperking) ontwikkelen geen functioneel taalgebruik en bevinden zich dus op de liminale grens van de sociale-symbolische orde; meestal wordt dit in klinisch onderzoek aangeduid als 'laag-functionerend autisme'. Dit niet-spreken wordt vaak, zoals hierboven al werd aangehaald, ervaren als problematisch en zet conventionele opvattingen over zelfbegrip vaak op losse schroeven:

$[\mathrm{T}]$ he silences of persons $[\ldots]$ frustrate therapeutic institutions whose restoration of persons to healthy normality through various modes of observation, assessment, and reorientation or behavior modification, all based on a concept 
of coherent and autonomous selfhood, has become so much part of contemporary life. ${ }^{35}$

Sommige individuen leren wel praten, maar zonder dat er altijd sprake zou zijn van functioneel taalgebruik en dus van betekenisvolle communicatie denk bijvoorbeeld aan (onmiddellijke of vertraagde) echolalie, het nazeggen of het voortdurend herhalen van een woord en/of zin in een bepaalde situatie. Leo Kanner, de kinderpsychiater die 'autisme' in de jaren veertig van de vorige eeuw op de psychiatrische kaart zette, toonde bijzonder veel interesse in dit fenomeen. Daar waar hij aanvankelijk zei dat dergelijk taalgebruik geen enkele betekenis had, nuanceerde hij dit later door de private referenties in echolalisch taalgebruik te onderkennen. De betekenissen van dergelijk taalgebruik zijn echter niet voor iedereen verstaanbaar, ze zijn niet universeel of essentieel te maken; ze hebben enkel betekenis op het kleinste niveau van het ik en kunnen slechts begrepen worden door mensen die ervaringen hebben gedeeld met de autistische persoon aan wie een uiting ooit werd gekoppeld: 'Lack of access to the source shuts out any comprehension, and the baffled listener, to whom the remarks means nothing, may too readily assume that it has no meaning at all. ${ }^{36}$

Het meest aangehaalde voorbeeld in de literatuur over echolalie is wellicht dat van Paul G ('case 4'), een van de kinderen die Kanner bestudeerde, die schijnbaar te pas en te onpas de zin 'Don't throw the dog off the balcony!' riep. Het was een zin die ooit door zijn moeder uitgesproken werd toen Paul een plastic speelgoedhondje van een hotelbalkon naar beneden wilde gooien. Wanneer Paul na het voorval de drang voelde opkomen om met iets te gooien, zei hij: 'Don't throw the dog off the balcony!' Deze directieve zin kan haast niet begrepen worden door iemand die de situatie niet kent. Toch functioneert echolalie hier niet als het betekenisloos nazeggen van woorden zonder enig doel, maar veeleer als een zelfdirectieve vorm van taalgebruik. Belangrijk is ook dat woorden eveneens niet-semantische mogelijkheden hebben, zo zijn fonetische kwaliteiten en akoestische patronen van woorden even belangrijk.

Wetenschappelijk onderzoek naar echolalie kwam relatief traag op gang. In 1985 herevalueerden Adriana L. Schuler en Barry M. Prizant echolalie als cognitief en communicatief relevant. Zowel direct als vertraagd echolalisch gedrag, zegt Prizant, 'is best described as a continuum of behaviors in regard to exactness of repetition, degree of comprehension, and underlying communicative intent'. ${ }^{37}$ Dit 'automaticity-intentionality continuum' is dus een continuüm dat gaat van meer automatische herhalin- 
gen van woorden naar meer intentionele en betekenisvolle uitingen of herhalingen. ${ }^{38}$

Heel wat mensen met autisme ontwikkelen ook functioneel (symbolisch) taalgebruik - zelfs een kind dat echolalisch gedrag vertoont, kan dergelijk taalgebruik ontwikkelen. ${ }^{39} \mathrm{Zij}$ zouden volgens neurocognitief onderzoek echter een verminderd vermogen tot intentioneel taalgebruik en symboolformatie vertonen. ${ }^{40}$ Specifiek worden er stoornissen op formeel, semantisch en pragmatisch niveau geïdentificeerd. Met formeel niveau doelt men op taalkundige aspecten als fonologie en syntax. Wat het fonologisch niveau betreft, suggereren onderzoeksresultaten vooral eigenaardigheden op het vlak van prosodie (vooral met betrekking tot vocale kwaliteit, intonatie en ritme). Op het syntactische en grammaticale niveau zou er echter te veel onderlinge variatie zijn om generaliserende conclusies te trekken. Onderzoeksresultaten duiden wel op een aantal terugkerende bijzonderheden op het semantische niveau, zoals het verkeerd gebruik van voornaamwoorden, idiosyncratisch gebruik van metaforen en neologismen, en moeilijkheden met figuratieve taal. Daarnaast zouden personen met autisme een opvallend rijke woordenschat kunnen hebben, maar zou er vaak een discrepantie zijn tussen de aanwezigheid van een rijke woordenschat en het begrijpen ervan. Ten slotte focust heel wat onderzoek op het pragmatische niveau van non-verbale en verbale communicatie bij mensen met autisme en identificeert daarbij voornamelijk moeilijkheden en stoornissen binnen het voeren van conversaties of het gebruik van narratieven. ${ }^{41}$

Binnen dergelijke onderzoeken worden verschillende theoretische kaders aangewend om de specifieke gedragingen, taal- en communicatiemoeilijkheden te verklaren alsook om ze te kunnen linken aan neurocognitieve verklaringen. Het oudste en meest gedocumenteerde theoretische kader is de 'Theory of Mind'-hypothese. ${ }^{42}$ Deze hypothese verbindt de sociale en communicatieproblemen bij mensen met autisme aan hun specifieke cognitieve moeilijkheden om eigen en andermans emoties (mental states) te interpreteren. ${ }^{43}$ De Theory of Mind-hypothese slaagt er echter niet in om de niet-sociale en niet-verbale elementen, die evenzeer een belangrijke rol spelen binnen taal- en communicatieontwikkeling, te verklaren. Mede daarom wordt er sinds anderhalve decennia steeds kritischer omgegaan met deze theorie. ${ }^{44}$

Een tweede veelvoorkomend denkkader is de 'executievefunctietheorie'. Executieve functies of besturingsfuncties is een verzamelnaam voor een scala aan mentale operaties dat cruciaal is bij onder meer het stap voor stap kunnen plannen, impulscontrole of zelfmonitoring. Via dit theo- 
retische kader is men erin geslaagd om verklaringen te vinden voor een aantal moeilijkheden of stoornissen dat niet meteen gerelateerd is aan sociale aspecten, zoals repetitief en stereotiep gedrag, moeilijkheden bij verandering van omgeving en planning. ${ }^{45}$ De executievefunctietheorie heeft echter minder tot geen aandacht voor opvallende (soms geïsoleerde) en heel specifieke talenten van mensen met autisme. Daarom focust recenter onderzoek dat zich bezighoudt met taal- en communicatieontwikkeling zich op de 'centralecoherentiehypothese', maar dan zonder de Theory of Mind- en executievefunctiehypotheses volledig te negeren.

De centralecoherentiehypothese - een derde theoretisch kader - gaat ervan uit dat mensen met autisme gewoonlijk een zwakkere centrale coherentie vertonen of een sterkere lokale coherentie. Lokale coherentie duidt op de meer fragmentarische (en volgens sommigen meer creatieve) manier van informatieverwerking bij mensen met autisme: in plaats van stimuli op een globale manier te interpreteren waarbij ook automatisch contextinformatie in rekening wordt gebracht (centrale coherentie), verloopt de informatieverwerking bij mensen op het spectrum minder samenhangend denk bijvoorbeeld aan de talrijke uitingen dat de wereld 'chaotisch overkomt'. Mensen met autisme worden veel meer aangetrokken door (lokale) details, zonder de context er (onmiddellijk) bij te zien en te interpreteren. Via deze centralecoherentiehypothese kan men zowel moeilijkheden als sterktes in kaart brengen. Zoals Bruce Mills aantoonde, laat het idee van lokale coherentie ook toe om af te stappen van de stereotiepe opvatting dat een zogenaamd 'autistisch brein' enkel op zichzelf is gericht, zonder enige interesse te hebben in andere personen of contexten. ${ }^{46}$ Het conceptualiseert autisme minder in termen van afwijking. Men spreekt veeleer van een specifieke cognitieve stijl met eigen vaardigheden. Tegelijkertijd is er ook binnen dit kader aandacht voor de moeilijkheden in symboolformatie in relatie tot zingeving in specifieke contexten: "The framework of the central coherence theory offers opportunities to conceptualize the language and communication problems in [Autism Spectrum Disorder] in terms of problems in the perception of meaning, or "sense-making". ${ }^{47}$

Het is opvallend dat het thema van lokale coherentie vaak aan bod komt in autismezelfverhalen. De al eerder aangehaalde auteur Williams beschrijft bijvoorbeeld hoe ze voortdurend haar lichaam opnieuw bij elkaar moet 'sprokkelen' om tot een geheel van ervaringen en gevoelens te komen, en hoe ze dus via het verzamelen van kleine deeltjes uiteindelijk een geheel en bij uitbreiding betekenis kan genereren: 'I had a fragmented perception of things at the best of times, seeing eyes or a nose or whiskers or a mouth but mostly putting the bits together in my head. ${ }^{48}$ Ook in 
Dubbelklik. Autisme bevraagd en beschreven (2004) van de Vlaamse kunstenaar Landschip, waar ik nog uitgebreider op zal ingaan, krijgen we talrijke 'illustraties' van lokale coherentie:

Het enige wat ik zeker weet is hoe ik het denken van anderen ervaar. Aan mijn ervaringen hoef ik niet te twijfelen. Ervaren is geen exacte wetenschap. Ervaren is iets heel persoonlijks. Ervaren is bovendien een raar woord: er varen zeilboten op de zee maar niet alle zeilers zijn ervaren. Ik heb nog maar een paar keer gevaren maar genoeg om iets te weten over de gevaren van het varen. De varen is bovendien ook nog eens een veelvoorkomende plant. En wie iets plant voert dat plan niet altijd uit. En is het uitvoeren van een plan ook onderhevig aan accijnzen? Of hangt dat af van het land waarnaar men het plan uitvoert? Het staat buiten kijf dat een veelvoorkomende plant iets goed is, want voorkomen is beter dan genezen. ${ }^{49}$

Daarnaast vertelt Landschip doorheen zijn oeuvre ook regelmatig 'over' zijn gevecht met de substituerende betekenisfunctie van taal. Zo lezen we: 'Ik verstond wel de woorden waarmee andere mensen praatten, maar toch snapte ik nooit goed waar ze het over hadden $[\ldots] .{ }^{50}$ Het feit dat woorden meer dan één betekenis kunnen hebben boezemde hem, zo vertelt hij, angst in omdat het meestal uiterste verwarring genereerde. ${ }^{51} \mathrm{De}$ meerduidigheid en bijgevolg onduidelijkheid van symbolisch taalgebruik doen Landschip immers 'verdwalen in de betekenis van elk onderdeeltje van een gedachte, ${ }^{52}$

Deze bovenstaande fragmenten duiden als 'illustraties' van lokale coherentie en moeilijkheden in verband met betekenisfunctie van taal is een veelvoorkomende interpretatieve strategie binnen autismeonderzoek. Taal en communicatie worden binnen die onderzoekstraditie, zoals gezegd, namelijk haast louter beschouwd als een representatiemechanisme, als een directe reflectie van een individuele cognitieve conditie. Er is binnen die redenering dan opnieuw sprake van een gesloten, stabiel en referentieel systeem. Dit impliceert dat er vooral wordt uitgegaan van slechts één mogelijke juiste of goede verhouding tot taal en communicatie: de rol van taal ligt bij voorbaat vast. ${ }^{53}$ Deze leeshouding zit er niet noodzakelijk naast: zowel Williams als Landschip geven aan dat ze inderdaad uitleg willen geven 'over' de lokale coherentie of gevecht met betekenisfunctie met taal. Niettemin is deze leeshouding niet de enige leeshouding die we zouden moeten hanteren. In het laatste deel van dit artikel gaan we met Landschips oeuvre uitgebreider in op het schetsen van de contouren van een alternatieve leeshouding. ${ }^{54}$ 
Met het benadrukken van de beperking van het representatieparadigma in klinisch onderzoek en het pleiten voor een alternatieve en dus bijkomende leeshouding wil ik zeker geen afbreuk doen aan de meer klinische en kwantitatieve studies naar autisme, taal en communicatie. Waar het me om gaat, is dat deze klinische studies voornamelijk steunen op een eenduidig en klassiek subjectiviteitsbegrip dat het idee dat een subject coherent en autonoom is naar voren schuift. Daarenboven laten ze opvallend weinig ruimte om kritisch te reflecteren over de categorie 'typisch' of 'normaal', of om limieten en ethische implicaties van een eenduidige visie op taal adequaat te theoretiseren. Willen we recht doen aan het heterogene karakter van autismezelfverhalen dan is het aangewezen om onder meer ook aandacht te schenken aan de act van het schrijven, aan de vorm en materialiteit van taal en dus aan andere verhoudingen tot taal, narrativiteit en subjectiviteit.

\section{Een ruimere verhaalnotie binnen autobiografische verhalen}

De vraag naar alternatieve benaderingen van taal, narrativiteit en bij uitbreiding zelfverhalen is in feite al lang geen nieuwe kwestie meer binnen autobiografische studies en life writing. Georges Gusdorf en Francis R. Hart wezen in het midden van de twintigste eeuw reeds op de illusie van het stabiele autobiografische subject: de transparantie van taal werd doorgeprikt als een culturele constructie. ${ }^{55}$ Ook autobiografische studies die werkten vanuit een feministisch perspectief bekritiseerden gretig het idee van een vaststaande, coherente subjectiviteit aan de hand van concepten als positionaliteit, performativiteit en relationaliteit. De life writing-theoreticus Paul John Eakin houdt zich in zijn oeuvre eveneens bezig met kritische reflecties over de narratieve identiteitsthese. Eakin gaat niet meer uit van een stabiel subject en evenmin, zo zegt hij, valt narrativiteit samen met een complete ervaring van dat subject: 'I should be careful to specify, that is expressed in self-narrations, for narrative is not (and cannot be) coextensive with all selfhood, given the multiple registers of selfhood [... ${ }^{56} \mathrm{Hij}$ doet opmerkelijk genoeg ook een paar pogingen om de correlatie tussen een verhaal en een gezond of ongezond zelf kritisch te bestuderen, maar besluit ten slotte: 'I am less interested, finally, in demonstrating that there is a link between narrative disorders and identity disorders than I am in pointing out that both clinicians (psychologists and neurologists) and conventionally socialized laymen make this link. ${ }^{57}$ 
Vanuit een narratologisch perspectief werd de coherentiethese ook al snel geproblematiseerd. Zo stelde Paul Ricoeur reeds in Time and Narrative (1984) de structuralistische reductie van narrativiteit in lineaire temporaliteit en thematische coherentie ter discussie. Hoewel dit werk uitkwam toen Jerome Bruner juist de narratieve identiteitsthese ten volle verdedigde, had Ricoeur opvallend weinig invloed tijdens de vroege periode van de 'narrative turn' en dus evenmin op Bruner. De poststructuralistische narratologie, die veeleer interesse heeft voor ongetemde en ongedisciplineerde verhalen, reageert evenzeer op de normatieve associatie tussen narrativiteit en coherentie - zowel de strekking die zich meer richt op fictionele verhalen ('unnatural narratology'), 58 als de strekking die literaire verhalen verbindt met dagelijks vertellen ('natural narratology'). ${ }^{59}$ Hoewel bovenstaande theorieën onderling verschillend zijn, stellen ze allen dat een (zelf)verhaal niet louter te reduceren is tot tijd en oorzaak; het is geen loutere aaneenschakeling van gebeurtenissen met een onderlinge causale band. Bijgevolg ondersteunen ze een bredere verhaalnotie; een die stelt dat een verhaal een voorstelling van zinvol gerelateerde gebeurtenissen is waarbij verschillende tekensystemen aan bod kunnen komen. ${ }^{60}$

Een dergelijk bredere verhaalnotie vond pas aan het begin van de eenentwintigste eeuw sporadisch ingang binnen meer empirisch gerichte onderzoeken vanuit de psychologie, antropologie of sociologie, die zich richten op zelfverhalen of verhalende aspecten in alledaagse gesprekken en situaties. Zo is het onderzoek van Elinor Ochs en Lisa Capps (2001) exemplarisch in die zin dat het ingaat tegen de dominantie van de strikte en traditionele notie van narratieve identiteit. Ochs en Capps zijn vooral geïnteresseerd in de therapeutische kracht van (zelf)verhalen en conversaties. Ze besteden aandacht aan welke invloed dagelijkse vertellingen kunnen hebben op ons geheugen en welke functie (zelf)verhalen en conversaties kunnen spelen op educatief vlak.

Opmerkelijk daarbij is dat ze een verhaal op een meer technisch niveau niet meer definiëren aan de hand van distinctieve of essentialistische kenmerken, maar veeleer kiezen voor een bredere verhaalnotie. Ze hanteren een set van graduele dimensies: een verhaal wordt gekenmerkt door een aaneenschakeling van (1) betekenisvolle elementen, (2) progressie (plot), die interageert met een (3) actant (agent, subject, identiteit). Daarnaast vertrekken ze vanuit een postmodern subjectbegrip. Ochs en Capps waarschuwen er tegelijkertijd voor dat een dergelijk postmodern perspectief op zijn beurt een subject kan 'opsluiten' in een vertoog, aangezien zo'n perspectief ervan uitgaat dat het vertoog het subject produceert. Om niet verstrikt te raken in een dergelijke visie, besteden ze uitgebreid aandacht 
aan hoe het subject aan de ene kant ontstaat in en door het vertoog, maar aan de andere kant evengoed een actieve vertooggebruiker kan worden in en door verhalen. Via de verhalen, die dus niet gestroomlijnd hoeven te zijn, wordt er ruimte gecreëerd voor reflectiviteit en ruimte waarin keuzes gemaakt kunnen worden.

Eenzelfde insteek vinden we in Storytelling in Daily Life (2004) van Kristin M. Langellier en Eric E. Peterson, een studie die zich voornamelijk toelegt op het concept van 'performatieve narrativiteit' binnen dagelijkse vertellingen en conversaties. Net zoals Ochs en Capps schenken ze beduidend veel aandacht aan de zinvolheid van fragmentatie en interactie binnen verhalen. Een laatste voorbeeld is het onderzoek van psychologe en systeemtherapeute Jasmina Sermijn dat zich focust op de vraag hoe een subject interageert met een psychiatrische diagnose. Sermijn vond de traditionele verhaalnotie (en bij uitbreiding narratieve identiteitsthese) te beperkt om recht te kunnen doen aan de zelfverhalen van haar cliënten. Ze keek vervolgens naar de postklassieke narratologie om tot een bredere verhaalnotie te komen en ging aan de slag met de ongetemde kenmerken binnen de zelfverhalen die ze vervolgens in verband bracht met de deleuziaanse metafoor van het rizoom. Volgens Sermijn is een zelfverhaal een rizomatisch verhaal met verschillende mogelijke ingangen en verschillende tijdelijke eenheden, net zoals het zelf rizomatisch en nooit eenduidig definieerbaar is. ${ }^{61}$

\section{$4 \quad$ Competente vertellers en ethiek}

Hoewel ze nog weinig tot niet in verband werden gebracht met autismezelfverhalen, bestaan er dus zeker andere manieren om te vertellen en om naar verhalen en subjecten te kijken dan die door zowel het klinische perspectief als de narratieve identiteitsthese en venstermetafoor naar voren werden geschoven. Inzichten uit de postklassieke narratologie beïnvloeden op productieve wijze steeds vaker empirisch onderzoek over zelfverhalen, waardoor het idee steeds breder gedragen wordt dat coherente zelfverhalen geen psychologische basis vormen voor subjectiviteit (en bij uitbreiding identiteit), maar dat het veeleer om een sociale constructie gaat. Het belang van de vraag wat een zelfverhaal verhalend maakt en de zoektocht naar andere mogelijke manieren van vertellen, heeft echter niet enkel een technische, maar ook een ethische dimensie.

Die ethische dimensie zien we aan het werk in Bérubés Life as We Know It (1996), de eerste memoir over zijn jongste zoon, Jamie, met het down- 
syndroom. Er is ook nog een andere zoon, Nick, zonder dit syndroom. Bérubé merkt op dat wanneer Nick opgroeit er automatisch verhalen worden verteld over de belangrijke mijlpalen van het kind, zoals de eerste happen, woorden en stappen. Diezelfde mijlpalen komen bij Jamie echter zo laat en zo traag dat het te gemakkelijk zou zijn om er niet over te praten. En hier ligt voor Bérubé het gevaar, want een leven dat niet verteld wordt, is te kwetsbaar voor vergetelheid en devaluatie. Willen we als subject $(\mathrm{h})$ erkend worden, moeten we immers vertellen.$^{62}$ De medisch socioloog Arthur W. Frank argumenteert dat een persoon die niet helemaal alleen en dus zonder assistentie kan vertellen, zoals de jonge Jamie, niet minder afhankelijk is van verhalen dan een fictioneel personage - dat is juist de kracht, zegt hij, van het verhalende argument: 'Stories make people narratable because they are inherently performative, which involves more than recognizing that telling stories is always something of a performance. Stories enact realities: they bring into being what was not there before. ${ }^{63}$

Frank heeft het hier niet over een (zelf)verhaal als een voorwaarde voor het ontstaan van een subjectiviteit, maar over hoe (zelf)verhalen iets teweeg kunnen brengen, zoals bijvoorbeeld (h)erkenning die er voordien nog niet was. Specifiek heeft hij het over activisme en het blootleggen van voorheen verzwegen geschiedenissen of gebeurtenissen. Enerzijds bevestigt de impact van autie-biografieën deze kracht van verhalen, want zo is men sinds de wildgroei van gepubliceerde autismezelfverhalen inderdaad anders gaan denken over het potentieel van mensen met autisme. Anderzijds kunnen normatieve conventies waarop zelfverhalen vaak steunen nefast zijn voor subjecten die buiten de 'norm' vallen, omdat ze bijvoorbeeld een niet-traditionele verhouding tot taal hebben. Frank erkent dit gevaar van een al te constructivistische visie op verhalen en stelt dan ook het volgende: 'Stories by themselves may not determine whether people have fuller or diminished lives, but by setting the terms in which lives are or are not narratable, stories create conditions for enrichment or diminishment. ${ }^{64}$

Wat er dus op het spel staat, zijn de voorwaarden voor verhalen, de mogelijke relaties tot taal en (zelf)verhaal, alsook de vraag of en hoe het (zelf)verhaal - en bij uitbreiding de interpretatie van dat (zelf)verhaal verrijkend kan zijn voor het vertellende danwel schrijvende subject. Als we dan toch moeten vertellen, is het dan ook mogelijk om de voorwaarden voor dat vertellen en voor wat verhaalbaar is - 'the terms in which lives are or are not narratable' - aan te passen en ons opnieuw af te vragen wat een 'competente verteller' is? Als we dat willen bereiken, dan moeten we een openheid creëren. Taal en narrativiteit moeten dan niet enkel worden be- 
schouwd in termen van geslotenheid en stabiliteit (bijvoorbeeld wanneer symbolisch en referentieel taalgebruik wordt gezien als norm), maar dan moet er ruimte worden gemaakt voor beweeglijkheid en openheid. Zoals de linguïst Valentin Voloshinov het verwoordde: taal en narrativiteit corresponderen 'to a still active social process, from which new meanings and possible meanings can be generated' ${ }^{65}$ Zo kunnen we subjecten die zich op een andere manier verhouden tot taal en narrativiteit erkennen als subjecten die in staat zijn te spreken voor en over zichzelf:

In this view of language, the conflation of dys-/disarticulation can be distangled. One is not irretrievably trapped in a structured totality of representation, knowledge production, and administration; and external, radical other is conceptually unnecessary, for otherness is always present in language and subjectivity. ${ }^{66}$

Het gaat er zeker niet om een al te eenvoudige oppositie te creëren tussen een ouderwetse stringente verhaalnotie enerzijds en een 'pomo-achtige', fluïde verhaalnotie anderzijds, maar om meerdere verhaalvormen of vormen van zelfexpressie te kunnen waarderen en aandacht te hebben voor hun gelaagdheid en eigenheid. Dit sluit aan bij het idee dat we autismezelfverhalen inderdaad kunnen lezen op het niveau van de symbolische orde - als teksten die verwijzen naar datgene wat 'buiten' de tekst ligt maar dat het daarbij niet mag blijven.

Het gaat in die teksten zelf, in de taal zelf, om méér dan betekenis alleen. De opvatting dat taal uitsluitend een medium is om naar een wereld buiten zichzelf te verwijzen, is te beperkt voor de mogelijkheden die taal auteurs als Tistje, Donna Williams, Larry Bissonnette Tito R. Mukhopadhyay, Amanda Baggs en vele anderen te bieden heeft. Aan de hand van een analyse van het werk van de Vlaamse kunstenaar Landschip zal ik hieronder een aanzet geven tot een alternatieve leespraktijk, waarbij er aandacht is voor andersoortige vormen van narratieve ordening en betekenisgeving. ${ }^{67}$

\section{$5 \quad$ Landschip}

Landschip (België, 1956-2017) is een pseudoniem van een, naar eigen zeggen, 'gemiddelde magere bruinharige mannelijke kunstzinnige autist van middelbare leeftijd, vooral voorkomend in de stadsrand van een gebied in West-Europa waar, ondanks de industriële vervuiling, ook reizigers, egels en hoogbejaarde fietsers worden waargenomen'. ${ }^{68}$ In de jaren 1980-1990 
hanteerde Landschip nog een reeks andere pseudoniemen (bijvoorbeeld: Ndizi Zinatosha en The Joseph Boys) en was hij voornamelijk actief als beeldend kunstenaar. Zijn werk werd opgepikt door het reguliere kunstencircuit en getoond in onder meer Marchandises. 5 millions de tonnes de marchandises livrées chaque année (1983) en De eerste Chauvenstische (1984), twee belangrijke tentoonstellingen voor de Belgische hedendaagse kunst die georganiseerd werden door het toenmalige Antwerps tentoonstellingsplatform Montevideo (1981-1985, Annie Gentils en Stan Peers). Vanaf de jaren 2000 verdwijnt Landschip echter uit het reguliere kunstcircuit en verschijnen er allerhande publicaties van zijn hand waarin hij uitdrukkelijk vertelt over zijn leven met autisme. Globaal genomen bestaat zijn oeuvre dus zowel uit schilderijen, installaties, tekeningen, als uit traditioneel gepubliceerde boeken, blogs en zelfs met de hand geschreven boeken.

Hierboven werd reeds aangestipt dat we Landschips teksten (en bij uitbreiding zijn tekeningen en schilderijen) op een symbolische manier kunnen lezen. Het citaat waarmee we reeds werkten, 'illustreerde' immers lokale coherentie. Dat we zijn teksten op een symbolische wijze kunnen lezen, wil echter niet zegen dat we het daarbij ook moeten laten. In taal gaat het immers vaak om meer dan representatie alleen. In plaats van de taal enkel iets 'over' de aard der dingen te laten vertellen, kunnen we proberen om vertrouwde taalopvattingen te doen kantelen; we kunnen proberen tegemoet te komen aan een 'autistische' hang naar concrete houvast door bijvoorbeeld, zoals cultuurwetenschapper Ruud Hendriks voorstelt, woorden los te weken uit hun betekenisvolle verband en meer aandacht te besteden aan de materie van de taal. ${ }^{69}$ Hiervoor moeten we de 'autist' volgen, want zoals Hendriks beargumenteert, kennen mensen op het spectrum hier beter de weg:

[N]iet omdat hij, zoals we tot nog toe geneigd waren te zeggen 'van binnen uit' een venster opent (waarmee van meet af aan een interpretatieve bias was ingebouwd); wél omdat hij beter dan niet-autistische taalgebruikers bestand is tegen de verleiding achter elke taaluiting een betekenis te zoeken. ${ }^{70}$

Het is precies wanneer we voorbij de substituerende functie van taal proberen te gaan dat er andere lagen in de tekst geïdentificeerd kunnen worden. Zo doet Landschip bijvoorbeeld méér dan enkel via taal rapporteren 'over' een ervaring. De onderhandelingen met de betekenisfunctie van taal materialiseren zich namelijk ook op vormelijk niveau, waardoor duidelijk wordt dat Landschip een productieve dimensie van taal verkiest boven 
haar traditionele reproductieve functie. Zoals we al merkten in het citaat dat lokale coherentie illustreert, heeft Landschip een doorgedreven associatieve schrijfstijl, zowel op woordniveau als in de tekststructuur. Om grip te krijgen op de meerduidige betekenissen van woorden, probeert hij verschillende combinaties uit. Hij doet de vertrouwde taalopvatting kantelen, hij draait de woorden binnenstebuiten en perst ze volledig uit:

Ja, die evolutie van 'invaliden' tot 'mindervaliden' tot 'andersvaliden'... Etymologisch kun je 'invalide' bovendien nog vertalen naar 'onwaardig'. Hoogst merkvalide eigenlijk. ${ }^{71}$

$[\mathrm{H}]$ oezo beeld-spraak? Beelden spreken toch niet? Betekent beeldspraak dan zwijgzaamheid? Betekent zwijgzaamheid 'in de stijl van Stefan Zweig'? Betekent "betekent" dat je er een tekening op maakt? ${ }^{72}$

Het 'altijd zo totaal' verdwalen in woorden, in betekenissen en in de wereld is echter ontzettend vermoeiend. ${ }^{73}$ Landschip geeft dan ook meermaals uiting aan zijn verlangen om te vluchten uit het referentiële taal- en communicatiesysteem. Om de semantische mogelijkheden van taal zo veel mogelijk naar de achtergrond te duwen ten voordele van de materialiteit van beeld en taal, scheurt hij boeken uit elkaar en bezweert hij de semantische capaciteit van de woorden door eroverheen te schilderen. ${ }^{74}$ In dat schilderen over woorden zit een specfiek verzet - een verzet dat niet zozeer gericht is op letters an sich, dan wel op de macht van taal met haar semantische, referentiële en communicatieve functies.

Landschip benadrukt ook regelmatig het belang van de rituele waarde en het fysieke aspect van schrijven en schilderen. Het schilderen, het maken van vormen en lijnen, is op zich een heel concrete activiteit:

De beeldassociaties staan los van het schilderen, dat voor mij in de eerste plaats voortkomt uit een motorisch proces waarbij ik lijnen, kleuren en vormen produceer alleen om het aangename gevoel dat ze me geven tijdens het schilderen. Dat het geschilderde een uitdrukking van iets is, dat is maar een vaststelling achteraf, ik start de schilderhandeling nooit vanuit een behoefte iets uit te drukken. ${ }^{75}$

$[\ldots]$ kleur is te belangrijk, ook in de zwartwitdingen, maar 't gaat ook om het werkelijk zien ontstaan van die lijnen en vormen. ${ }^{76}$

Conventioneel taalgebruik schiet dus voor Landschip tekort om uiting te geven aan zijn ervaringen. Hij heeft een expliciete voorkeur voor het voorwerpkarakter van letters, lijnen en kleur, ook wel grammatekstualiteit ge- 
noemd. Grammatekstualiteit is als het ware het grafische equivalent van Roman Jakobsons 'poëtische functie' of 'literariteit' en werd aanvankelijk in 1984 door de Franse theoreticus Jean-Gérard Lapacherie geconceptualiseerd. Meer recentelijk wordt de term vaak aangewend in comics studies en mediaonderzoek. Binnen die laatste studiedomeinen legt Terry Harpold het concept als volgt uit:

Jean-Gérard Lapacherie [...] has stressed the need for a critical vocabulary for describing aspects of written and printed texts that are autonomous with regard to the production of speech. In texts in which this autonomy is in evidence, he observes, the 'graphic substance' of the letter, line, and page, are foregrounded or are otherwise independent of the 'phonic substance' and discursive structures they may also represent. ${ }^{77}$

Die expliciete voorkeur voor de grammatekstualiteit laat het toe Landschips teksten, de met de hand geschreven notities, alsook zijn schilderijen en tekeningen te begrijpen als een ordeningsmechanisme met zowel een verwijzende als lokale kwaliteit. Het gaat daarbij dus niet louter om de representatieve en (conventioneel) poëtische functies van taal, maar ook om de voorliefde voor het voorwerpkarakter van taal aanwezig in de tekst. Deze precategorische of indexicale en materiële verhouding zijn net zo belangrijk als een symbolische verhouding. ${ }^{78}$ Hetgeen óver de tekst heen wordt geschilderd kan 'misschien-wellicht-eventueel ${ }^{\text {79 }}$ verwijzen naar een wereld buiten zichzelf, maar het accent ligt voor Landschip toch voornamelijk op de lokale ordening ('dat motorische proces met het aangename gevoel'), op de werkelijke actie die ter plekke plaatsvindt op 'dat oude papier met de specifieke geur' ${ }^{80}$. Hij creëert daarmee een besloten wereld voor zichzelf, een ruimte waarin het onderscheid tussen de afbeelding enerzijds en de concrete werkelijkheid anderzijds plaatsmaakt voor nieuwe patronen: 'Net als mijn innerlijke taal dient het schilderen niet om te communiceren maar om iets voor mezelf te registreren. ${ }^{, 81}$

Het belang van dit ordeningsmechanisme, van het lokale en materiële náást het symbolische, wordt echter zelden erkend, laat staan getheoretiseerd binnen onderzoek dat zich focust op autisme, taal en narrativiteit. De symbolische verhouding tot taal (en bij uitbreiding centrale coherentie) wordt steeds als beter en juister beschouwd dan bijvoorbeeld de indexicale verhouding tot taal (en bij uitbreiding lokale coherentie). Anders gezegd, er wordt uitgegaan van een normaliteitsbegrip, vaak gematerialiseerd in 'controlegroepen' met 'typische' taal- en communicatieontwikkeling, en 
alles wat daarvan verschilt, wordt geïnterpreteerd als een zwakte, afwijking of stoornis.

\section{Ter conclusie}

In deze bijdrage ging ik aan de slag met de complexe spanning tussen de diagnose autismespectrumstoornis enerzijds en taal en narrativiteit anderzijds. Ik exploreerde die spanning aan de hand van de receptie van autismezelfverhalen, de veel gehanteerde venstermetaforiek, enkele klinische perspectieven en de (vaak dominante) narratieve identiteitsthese. Daarbij werd duidelijk dat het belang van (zelf)verhalen alom erkend wordt willen we (h)erkend worden als subject, dan eist het systeem immers een (zelf)verhaal. Maar dat (zelf)verhaal wordt binnen autismeonderzoek (en onderzoek naar disability life narratives in het algemeen) nog heel vaak op een specifieke en normatieve manier geconceptualiseerd. Dit heeft echter verregaande gevolgen in het $(\mathrm{h})$ erkennen van subjecten die moeilijker vertellen, van subjecten die niet steeds of zelfs geen conventionele taal hanteren. Bovendien wordt hierdoor ook de creativiteit en gelaagdheid van sommige zelfverhalen, zoals die van Landschip, niet onderkend.

Het is mede op dit vlak, zo is hopelijk duidelijk geworden, waar literatuurstudie een belangrijke bijdrage kan leveren aan het veld van de medical humanities: onderzoek naar life writing en het effect van leeshoudingen legt specifieke normatieve verhoudingen tot taal, narrativiteit en communicatie bloot en 'denaturaliseert' deze vervolgens, waardoor recht kan worden gedaan aan de complexiteit van autistische subjecten. Via het oeuvre van Landschip toonde ik alvast kort aan hoe beduidend het is om ook voorbij te gaan aan een louter symbolische lezing of de substituerende functie van taal. Alleen dan konden we recht doen aan de rijkheid van Landschips werk, werd het belang van schrijven, tekenen en schilderen als lokaal ordeningsmechanisme duidelijk, evenals de indexicale verhouding tot taal en de sterke voorkeur voor de materiële kwaliteit van taal. Om blijvend recht te doen aan dergelijke zelfverhalen, is het onontbeerlijk om ons zowel op een meer technisch als op ethisch niveau telkens opnieuw af te vragen wat een zelfverhaal is, wie mag en kan spreken, en wie bijgevolg al dan niet beschouwd wordt als een competent verteller - en bij uitbreiding als volwaardig subject. 


\section{Noten}

1. Het woord 'autisme' slaat hier steevast op het gehele autismespectrum (inclusief de oudere diagnose Aspergersyndroom). Wanneer ik naar de diagnostische categorie op zich verwijs zoals beschreven in de $D S M-5$ dan hanteer ik de term 'autismespectrumstoornis'.

2. Hacking (2009), 1469; zie ook Smith (1996); Murray (2008); Osteen (2008).

3. Murray (2006), 25 .

4. Deze fascinatie voor autisme hangt samen met die van de fascinatie voor het brein. Het brein - waar zich de zogenaamde 'oorzaak' van autisme zou bevinden - is sinds de jaren 1990 uitgegroeid tot een soort populair cultuur icoon. Voor een doortastende analyse van neurologie en het brein binnen de (populaire) cultuur, zie Abi-Rached \& Rose (2013).

5. Ondertussen groeit dit veld zelfs zodanig snel dat disability studies-onderzoekers Rachel Mallett en Katherine Runswick-Cole kritische vragen stellen bij de veelheid aan academische aandacht: autisme is een academisch product of 'capitalist commodity' geworden, zeggen ze (Mallet \& Runswick-Cole [2012], 33). Ze beschouwen op kritische wijze de proliferatie aan academisch onderzoek als deel van de 'contemporary consumer culture'. Leunend op commodificatietheorieën onderzoeken ze vervolgens welke implicaties de groei en veelheid van onderzoek over 'autisme' hebben in het produceren en consumeren van autisme.

6. Zie bijvoorbeeld Happé (1991); Dix (2017).

7. Bérubé (2016), 130; zie ook Savarese (2010); Van Goidsenhoven \& Masschelein (2016).

8. Van Goidsenhoven \& Masschelein (2016).

9. Dit vooral in de Angelsaksische wereld en Europa. Binnen Europa is Frankrijk echter een uitzondering; daar zijn heel weinig zelfverhalen van mensen met autisme gepubliceerd. Verder is er relatief weinig informatie over dergelijke zelfverhalen uit Oost-Europa, Afrika en Azië.

10. Smith (1996); Eakin (1999); Osteen (2008); Osteen (2013).

11. Happé (1991), 207.

12. Specht in Zöller (1989), 7 .

13. Rimland in Grandin \& Scariano (2005), 3; cursivering LvG.

14. Rimland in Williams (1992), 2; cursivering LvG.

15. Sacks in Grandin (2005), 11.

16. Klonovsky (1993), 9 .

17. Zie bijvoorbeeld Hendriks (2000); Murray (2008); Savarese (2010).

18. Peeters op kaft van Dumortier (2012); cursivering LvG.

19. Thienpont (2017), 8; cursivering LvG.

20. Wexler (2016), 10; cursivering LvG.

21. Osteen (2008), 17.

22. Kern-Stähler \& Thiemann (2015), 20.

23. Osteen (2008), 261.

24. Osteen (2008), 21; zie ook Losh \& Capps (2003); Osteen (2013).

25. Bruner (1986); Bruner (1990); Gergen (1989); Holstein \& Gubrium (2000).

26. Damasio in Medved \& Brockmeier (2010), 18; cursivering in origineel.

27. Gazzaniga in Medved \& Brockmeier (2010), 18.

28. Wat echter niet mag worden vergeten is dat wanneer Aristoteles de noties 'coherentie' en 'verhaal' definieerde, hij het niet had over autobiografische verhalen en een eventu- 
ele rechtstreekse link met de psyche of het zelf. Hij had het niet over diëgese, maar over mimesis, over drama en meer bepaald de tragedie. Maria Medved en Jens Brockmeier $(2010,20)$ merken bovendien terecht op dat het concept coherentie bij Aristoteles behoorlijk complex is, terwijl de studies die zich buigen over de correlatie tussen het zelf en narratieve coherentie het concept coherentie op een veel minder complexe manier begrijpen en definiëren (bijvoorbeeld: enkel op basis van tijd of thema). Jerome Bruner was een van de enigen die wel ambivalenter was over het belang van het coherentieconcept.

29. Phelan (1989).

30. Frissen \& De Mul (2000), 16.

31. Zie bijvoorbeeld McAdams (2003); Lysaker, Wickelt \& Davis (2005).

32. Zie bijvoorbeeld Davidson \& Strauss (1992); McAdams (2006).

33. Ik ontken niet dat er sociaal-emotionele en communicatieve moeilijkheden zijn wanneer men zich niet of moeilijk kan uiten via verhalen en conventionele taal. Ook de eenzaamheid, pijn en frustratie die kunnen voortvloeien uit het moeilijker of anders spreken dienen aandacht te krijgen en te worden getheoretiseerd.

34. Kanner (1943); Wing (2001); Maljaars e.a. (2012).

35. Smith (1996), 232; cursivering LvG.

36. Kanner (1946), 243.

37. Prizant (1983), 64.

38. Schuler \& Prizant (1985), 176.

39. Volgens Schuler \& Prizant $(1985,175)$ evolueert het kind dan van een 'gestalt processing style' naar een meer 'analytisch denken': 'Some autistic persons, however, do move out of primarily echolalic language to more productive and flexible language. For these individuals, language acquisition appears to involve movement to a more analytic mode allowing for rule induction and resulting in the analysis and segmentation of gestalt forms, with linguistic rule induction $[\ldots]$, as well as other rules pertaining to, for example, symbolic play and social interaction.'

40. Noens \& Van Berckelaer-Onnes (2004); Maljaars et al. (2012).

41. Losh \& Capps (2003); Noens \& Van Berckelaer-Onnes (2004).

42. Frith \& Happé (1994); Baron-Cohen (1995), (2000).

43. De Villiers (2000).

44. Plaisted (2000); Noens \& Van Berckelaer-Onnes (2004).

45. Bailey e.a. (1996); Liss e.a. (2001).

46. Mills (2008).

47. Noens \& Van Berckelaer-Onnes (2004), 126.

48. Williams (1999), 162.

49. Landschip (2002), 192.

50. Landschip \& Modderman (2004), 60.

51. Landschip \& Modderman (2004), 31, 131.

52. Landschip \& Modderman (2004), 193.

53. Het is niet de bedoeling om hier een exhaustief overzicht te geven van taal- en communicatieonderzoek in autisme, dan wel om kort de dominante trend te laten zien. Er bestaan echter ook recente autismeonderzoeken die proberen in te gaan tegen deze dominante houding en dus een eenduidige visie op taal als gesloten, verbaal, referentieel systeem problematiseren; zie bijvoorbeeld Sterponi e.a. (2016).

54. Het gaat hier niet om het ontkennen van de moeilijkheid die gepaard gaat met het opstellen van communicatieprofielen binnen klinisch onderzoek dat zich richt op de taalontwikkeling van mensen met autisme ontkennen. Die complexiteit is er zeker: zij 
heeft te maken met methodologische moeilijkheden, maar daarnaast blijken de communicatievaardigheden ook nog eens enorm heterogeen te zijn bij mensen met een diagnose autisme - en door de toenemende erkenning van autisme bij verbale mensen wordt dit alleen nog maar gecompliceerder. Daarenboven is er sprake van progressie in verschillende taal- en communicatiefuncties naarmate mensen met een diagnose ouder worden. Er zijn echter weinig tot geen longitudinale studies die dit al ten volle in kaart brengen. De meeste onderzoeken focussen immers uitsluitend op (heel jonge) kinderen. Neurocognitief en meer kwantitatief onderzoek rond autisme, taal- en communicatieontwikkeling is zeker waardevol en moet blijvend ondersteund worden.

55. Gusdorf (1980); Hart (1970).

56. Eakin (1999), 101.

57. Eakin (1999), 140-141.

58. Zie Richardson (2006); Alber \& Heinze (2011).

59. Zie Fludernik (1996); Herman (1999); Herman (2002); Nünning e.a. (2010).

6o. Herman \& Vervaeck (2005), 21.

61. Sermijn e.a. (2008).

62. Butler (2005); Smith \& Watson (2010).

63. Frank (2010), 75; cursivering in origineel.

64. Frank (2010), 75 .

65. Voloshinov in Berger (2014),188.

66. Berger (2014), 59 .

67. Wil men (gepubliceerde) autismezelfverhalen analyseren is het bovendien ook belangrijk aandacht te schenken aan het prescriptieve werk van autisme als categorie op de zelfverhalen en omgekeerd, de invloeden en effecten van de institutionele context, de verhouding tot het therapeutische zelfhulpethos, de technologieën van het zelf en de disciplinerende machten die de zelfverhalen doen ontstaan en vervolgens in en door de verhalen opnieuw worden gereproduceerd.

68. Landschip (2002), 5 .

69. Hendriks (2000), 172 .

70. Hendriks (2000), 172.

71. Landschip \& Modderman (2004), 92.

72. Landschip \& Modderman (2004), 131.

73. Landschip \& Modderman (2004), 196.

74. Landschip \& Modderman (2004), 138-139.

75. Landschip \& Modderman (2004), 133.

76. Landschip \& Modderman (2004), 141.

77. Harpold in Baetens \& Frey (2015), 152-153.

78. In tegenstelling tot een symbool verwijst een indexicaal teken enkel en alleen naar een specifiek object. We zouden zelfs kunnen zeggen dat het ding voor het woord staat in plaats van omgekeerd.

79. Landschip (2002), 9.

8o. Landschip \& Modderman (2004), 138-139.

81. Landschip \& Modderman (2004), 133. 


\section{Literatuur}

Abi-Rached, J.M. \& Rose, N., Neuro. The New Brain and the Management of the Mind, Princeton University Press, Princeton, 2013.

Alber, J. \& Heinze, R., Unnatural Narratives, Unnatural Narratology, De Gruyter, Berlijn, 2011.

Baetens, J. \& Frey, H., The Graphic Novel. An Introduction, Cambridge University Press, New York, 2015 .

Bailey, A., Phillips, W. \& Rutter, M., 'Autism. Towards an Integration of Clinical, Genetic, Neuropsychological and Neurobiological Perspectives,' in: Journal of Child Psychology and Psychiatry 37, 1996, 1, 89-126.

Baron-Cohen, S., Mindblindness. An Essay on Autism and Theory of Mind, MIT Press, Cambridge, 1995 .

Baron-Cohen, S., 'Theory of Mind and Autism. A Fifteen-Year Review', in: Baron-Cohen S., TagerFlusberg, H. \& Cohen, D.J. (red.), Understanding Other Minds. Perspectives from Developmental Cognitive Neuroscience, Oxford University Press, New York, 2000, 3-20.

Berger, J., The Disarticulate. Language, Disability, and the Narratives of Modernity, New York University Press, New York, 2014.

Bernlef, J., Vallende ster, Querido, Amsterdam, 1989.

Bérubé, M., Life as We Know It. A Father, A Family, and an Exceptional Child, Pantheon Books, New York, 1996.

Bérubé, M., The Secret Life of Stories. From Don Quixote to Harry Potter, How Understanding Intellectual Disability Transforms the Way We Read, New York University Press, New York, 2016.

Bruner, J., Actual Minds, Possible Worlds, Harvard University Press, Cambridge, 1986.

Bruner, J., Acts of Meaning, Harvard University Press, Cambridge, 1990.

Butler, J., Giving an Account of Oneself, Fordham University Press, New York, 2005.

Davidson, L. \& Strauss, J.S., 'Sense of Self in Recovery from Mental Illness', in: British Journal of Medical Psychology 65, 1992, 2, 131-145.

Dix, A., 'Becoming Visible. Identifying and Empowering Girls on the Autistic Spectrum through Dramatherapy', in: Haythorne, D. \& Seymour, A. (red.), Dramatherapy and Autism, Routledge, London, 2017, 66-80.

Dumortier, D., Van een andere planteet, Houtekiet, Antwerpen, 2012.

Eakin, P.J., How Our Lives Become Stories. Making Selves, Cornell University Press, Ithaca, 1999.

Fludernik, M., Natural Narratology, Routledge, London, 1996.

Frank, A.W., Letting Stories Breathe. A Socio-Narratology, University of Chicago Press, Chicago, 2010.

Frissen, V. \& De Mul, J., Under construction. Persoonlijke en culturele identiteit in het multimediatijdperk, Infodrome, Amsterdam, 2000.

Frith, U. \& Happé, F., 'Autism. Beyond the "Theory of Mind”', in: Cognition 50, 1994, 1-3, 115-132.

Gergen, K.J., 'Warranting Voice and the Elaboration of the Self, in: Shotter, J. \& Gergen, K.J. (red.), Texts of Identity, Sage, London, 1989, 70-81.

Goidsenhoven, van L. \& Masschelein, A., 'Donna Williams's “Triumph". Looking for "the Place in the Middle" at Jessica Kingsley Publishers', in: Life Writing 13, 2016, 2, 1-23.

Grandin, T. \& Scariano, M.M., Emergence Labeled Autistic, Grand Central Publication, New York, [1986] 2005 .

Gusdorf, G., 'Conditions and Limits of Autobiography', in: Olney, J. (red.), Autobiography. Essays Theoretical and Critical, Princeton University Press, New Jersey, 1980, 28-48. 
Hacking, I., 'Autistic Autobiography', in: Philosophical Transition of the Royal Society B. Biological Sciences 364, 2009, 1522, 1467-1473.

Haddon, M., The Curious Incident of the Dog in the Night-Time, Vintage, London, 2003.

Happé, F., 'The Autobiographical Writings of Three Asperger Syndrome Adults. Problems of Interpretation and Implications for Theory', in: Frith, U. (red.), Autism and Asperger Syndrome, Cambridge University Press, Cambridge, 1991, 207-242.

Hart, F., 'Notes for an Anatomy of Modern Autobiography', in: Spring 1, 1970, 3, 485-511.

Hendriks, R., Autistisch gezelschap. Een empirisch-filosofisch onderzoek naar het gezamenlijk bestaan van autistische en niet-autistische personen, Swets \& Zeitlinger Publishers, Lisse, 2000.

Herman, D., 'Introduction. Narratologies', in: Herman, H. (red.), Narratologies. New Perspectives on Narrative Analysis, Ohio State University Press, Columbus, 1999, 1-30.

Herman, D., Story Logic, University of Nebraska Press, Lincoln, 2002.

Herman, L., Vervaeck B., Vertelduivels. Handboek voor verhaalanalyse, VUBPress/Vantilt, Brussel, 2005 .

Holstein J.A. \& Gubrium, J.F., The Self we Live by. Narrative Identity in a Postmodern World, Oxford Books, New York, 2000.

Kanner, L., 'Autistic Disturbances of Affective Contact', in: Nervous Child 2, 1943, 3, 217-250.

Kanner, L., 'Irrelevant and Metaphorical Language in Early Infantile Autism', in: American Journal of Psychiatry 103, 1946, 2, 242-246.

Kern-Stähler, A. \& Thiemann, A., 'Autism and the American Dream. Progress and Recovery in the American Autie-Biography', in: Gygax, F. \&Licher, M.A. (red.), Narrative Matters in Medical Context across Disciplines, John Benjamins Publishing Company, Amsterdam, 2015, 17-31.

Klonovsky, M., 'In plaats van een inleiding', in: Sellin, B., ik wil geen inmij meer zijn. berichten uit een autistische kerker, Thoth, Bussum, 1993, 7-13.

Landschip, De onzichtbare autist, Vlaamse Vereniging Autisme, Gent, 2002.

Landschip \& Modderman, L., Dubbelklik. Autisme bevraagd en beschreven, EPO, Antwerpen, 2004. Langellier K.M. \& Peterson, E.E., Storytelling in Daily Life, Temple University Press, Philadelphia, 2004.

Liss, M., Fein, D., Allen, D., Dunn, M., Feinstein, C. \& Morris, R., 'Executive Functioning in Highfunctioning Children with Autism', in: Journal of Child Psychology and Psychiatry 42, 2001, 2, 261-270.

Lord, C., Risi, S. \& Pickles, A., 'Trajectory of Language Development in Autism Spectrum Disorders', in: Rice, M. \& Warren, S. (red.), Developmental Language Disorders. From Phenotypes to Etiologies, Lawrence Erlbaum, Mahwah, 2004, 7-29.

Losh, M. \& Capps, L., 'Narrative Ability in High-Functioning Children with Autism or Asperger's Syndrome', in: Journal of Autism and Developmental Disorders 33, 2003, 3, 239-251.

Lysaker, P., Wickelt, A.M. \& Davis, L.W., 'Narrative Qualities in Schizophrenia. Associations with Impairments in Neurocognition and Negative Symptoms', in: The Journal of Nervous and Mental Disease 193, 2005, 4, 244-249.

Maljaars, J., Noens, I., Scholte, E. \& Van Berckelaer-Onnes, I.A., 'Language in Low-Functioning Children with Autistic Disorder. Differences Between Receptive and Expressive Skills and Concurrent Predictors of Language', in: Journal of Autism and Developmental Disorders 42, 2012, 2, 2181-2191.

Mallett, R. \& Runswick-Cole, K., Approaching Disability. Critical Issues and Perspectives, Routledge, London, 2014 .

McAdams, D.P., 'Identity and the Life Story', in: Fivush, R. \& Haden, C. (red.), Autobiographical Memory and the Construction of a Narrative Self. Developmental and Cultural Perspectives, Lawrence Erlbaum Associates, Mahwah, 2003, 187-207. 
McAdams, D.P., The Redemptive Self. Stories Americans Live By, Oxford University Press, Oxford, 2006.

Medved, M.I. \& Brockmeier, J., 'Weird Stories. Brain, Mind, and Self, in: Hyvärinen M., Hydén, L. H., Saarenheimo, M. \& Tamboukou, M. (red.), Beyond Narrative Coherence, John Benjamins Publishing Company, Amsterdam, 2010, 16-32.

Mills, B., 'Autism and the Imagination', in: Osteen, M. (red.), Autism and Representation, Routledge, London, 2008, 117-132.

Murray, S., 'Autism and the Contemporary Sentimental. Fiction and the Narrative Fascination of the Present', in: Literature and Medicine 25, 2006, 1, 24-45.

Murray, S., Representing Autism. Culture, Narrative, Fascination, Liverpool University Press, Liverpool, 2008.

Noens, I. \& Van Berckelaer-Onnes, I.A., 'Captured by Details. Sense-Making, Language and Communication in Autism', In: Journal of Communication Disorders 38, 2004, 2, 123-141.

Nünning, V., Nünning, A. \& Neumann, B. Cultural Ways of Worldmaking. Media and Narratives, De Gruyter, Berlijn, 2010.

Ochs, E. \& Capps, L., Living Narrative. Creating Lives in Everyday Storytelling, Harvard University Press, Cambridge, 2001.

Osteen, M. (red.), Autism and Representation, Routledge, London, 2008.

Osteen, M., 'Narrating Autism', in: Davidson, J. \& Orsini, M. (red.), Worlds of Autism. Across the Spectrum of Neurological Difference, University of Minnesota Press, Minneapolis, 2013, 261284.

Phelan, J., Reading People, Reading Plots. Character, Progression, and the Interpretation of Narrative, University of Chicago Press, Chicago, 1989.

Plaisted, K. C., 'Aspects of Autism that Theory of Mind Cannot Explain', in: Baron-Cohen, S., Tager-Flusberg, H. \& Cohen, D.J. (red.), Understanding Other Minds. Perspectives from Developmental Cognitive Neuroscience ( $2^{\text {nd }}$ edition), New York University Press, New York, 200o, 222-250.

Prizant, B.M., 'Echolalia in Autism. Assessment and Intervention', in: Seminars in Speech and Language 4, 1983, 1, 63-77.

Richardson, B., Unnatural Voices. Extreme Narration in Modern and Contemporary Fiction, Ohio State University Press, Columbus, 2006.

Ricoeur P., Time and Narrative (Vol. 1), University of Chicago Press, Chicago, 1984.

Savarese, R.J., 'Toward a Postcolonial Neurology. Autism, Tito Mukhopadhyay, and New GeoPoetics of the Body', in: Journal of Literary \& Cultural Disability Studies 4, 2010, 3, 273-290.

Schuler, A.L. \& Prizant, B.M., 'Echolalia', in: Schopler, E. \& Meisbov, G.B. (red.), Communication Problems in Autism, Plenum, New York, 1985, 163-184.

Sermijn, J., Devlieger, P. \& Loots, G., 'The Narrative Construction of the Self. Selfhood as a Rhizomatic Story', in: Qualitative Inquiry 14, 2008, 4, 632-650.

Smith, S., 'Taking It to a Limit One More Time. Autobiography and Autism', in: Smith, S. \& Watson, J. (red.), Getting a Life. Everyday Uses of Autobiography, University of Minnesota Press, Minnesota, 1996, 226-246.

Smith, S. \& Watson, J., Reading Autobiography. A Guide for Interpreting Life Narratives, University of Minnesota Press, Minnesota, 2010.

Sterponi L., De Kirby, K. \& Shankey, J., 'Rethinking Language in Autism', in: Autism 19, 2016, 5, 517526.

Thienpont, L. (red.), De pijn van anders zijn. Getuigenissen van (on)draaglijk lijden met Asperger, Acedemia Press, Gent, 2017.

Travis, L.L. \& Sigman, M., 'Communicative Intentions and Symbols in Autism. Examining a Case of Altered Development', in: Burack, J. A., Charman, T., Yirmiya, N. \& Zelazo, P.R. (red.), The 
Development of Autism. Perspectives from Theory and Research, Erlbaum, Mahwah, 2001, 279308.

Villiers, de J., 'Language and Theory of Mind. What Are the Developmental Relationships?', in: Baron-Cohen, S., Tager-Flusberg, H. \& Cohen, D.J. (red.), Understanding Other Minds. Perspectives from Developmental Cognitive Neuroscience, Plenum Press, Oxford, 2000, 83-123.

Wexler, A., Autism in a Decentered World, Routledge, London, 2016.

Williams, D., Nobody Nowhere. The Remarkable Autobiography of an Autistic Girl, Doubleday, New York, 1992.

Williams, D., Like the Colour to the Blind. Soul Searching and Soul Finding, Jessica Kingsley Publishers, London, 1999.

Wing, L., The Autistic Spectrum. A Parents' Guide to Understanding and Helping Your Child, Ulysses Press, Berkeley, 2001.

Zöller, D., Wenn ich mit euch reden könnte..., Scherz Verlag, Bern, 1989.

\section{Over de auteur}

Leni Van Goidsenhoven studeerde kunstenwetenschappen aan de UGent en literatuurwetenschappen aan de KU Leuven. Ze promoveerde in 2017 met het proefschrift Autisme in veelvoud. Het potentieel van life writing voor alternatieve vormen van subjectiviteit en is werkzaam als doctor-assistent aan de KU Leuven binnen de vakgroep Culturele Studies. Ze is auteur van de catalogus Middle Gate Geel'iz. Curator Jan Hoet (2013) en publiceerde o.a. in Qualitative Inquiry, Language, Literature and Culture en Psychoanalytische Perspectieven.

E-mail: leni.vangoidsenhoven@kuleuven.be 